\title{
Natural occurrence of the Fusarium solani on Tityus stigmurus (Thorell, 1876) (Scorpiones: Buthidae)
}

\author{
Santana-Neto, PL. ", Albuquerque, CMR. ${ }^{\mathrm{a} *}$, Silva, APP. ${ }^{\mathrm{b}}$, Svedese, $V M .^{\mathrm{b}}$ and Lima, EALA. ${ }^{\mathrm{b}}$

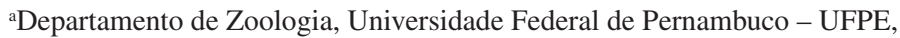 \\ Av. Morais Rego, s/n, CEP 50570-420, Recife, PE, Brazil \\ ${ }^{\text {b}}$ Departamento de Micologia, Universidade Federal de Pernambuco - UFPE, \\ Av. Morais Rego, s/n, CEP 50570-420, Recife, PE, Brazil \\ *e-mail: cleide.ufpe@gmail.com \\ Received July 152008 - Accepted November 12, 2008 - Distributed February 28, 2010
}

(With 1 figure)

\begin{abstract}
Members of the Fusarium solani species complex are agents of human mycoses, also affecting plants and other animals. Nevertheless, this fungus has not been reported on scorpions. Ten specimens of Tityus stigmurus collected in the field and showing their surface covered by white mycelia were used to assess fungus presence in the animal after its death. Identification of the fungi was based upon the cultural and morphological characteristics. The fungus was isolated from chelicerae and intersegmental regions. Infected individuals had their behaviour modified by reducing feeding and locomotion. None of the infected individuals survived. It is likely that this fungus may have a role in the regulation of field scorpion populations.
\end{abstract}

Keywords: scorpion, fungus infection, animal behavior.

\section{Ocorrência natural de Fusarium solani em Tityus stigmurus (Thorell, 1876) (Scorpions: Buthidae)}

\section{Resumo}

Ocorrência natural de Fusarium solani em Tityus stigmurus (Thorell, 1876) (Scorpiones: Buthidae). Membros do complexo de espécies de Fusarium solani são freqüentemente referidos como agentes de micoses humanas, podendo também afetar plantas e outros animais. Contudo, esse fungo ainda não foi registrado como causador de infecções em escorpiões. Dez espécimes de Tityus stigmurus coletados em campo e apresentando micélio branco cobrindo a superfície do corpo foram usados para analisar a presença de fungo após a sua morte. A identificação do fungo foi baseada nas características da cultura e morfológicas. O fungo foi isolado de quelíceras e regiões intersegmentais. Indivíduos infectados tiveram seu comportamento modificado, reduzindo sua alimentação e locomoção. Nenhum dos indivíduos infectados sobreviveu. É possível que este fungo possa ter um papel na regulação da população de campo desse escorpião.

Palavras-chave: escorpião, infecção por fungo, comportamento animal.

\section{Introduction}

Tityus stigmurus (Thorell, 1876) belongs to the Buthidae family which has approximately 550 of the 1,500 known scorpion species (Lourenço and Eickstedt, 2003). The genus Tityus (Koch, 1836) comprises the largest species number of the Scorpiones order, and has a wide geographic distribution in South America. In Brazil, almost 60 species of Tityus genus has been recorded, three of which, T serrulatus Lutz \& Mello, 1922, T. bahiensis (Perty, 1833) and T. stigmurus are responsible for serious and fatal accidents to humans (Lira da Silva et al., 2000; Brasil, 2001; Soares et al., 2002).
Several parasites including bacteria, virus and fungus have been described as caustive agents of natural scorpion infection (Matthiesen, 1984). Fusarium spp are described as a group of saprophagic soil fungi and plant pathogen with a wide range of hosts, as well as being a causative agent of superficial and systemic infections in humans and animals (Romano et al. 1998; Godoy et al. 2004; Zhang et al. 2006). In arthropods, one of the most common Fusarium species, Fusarium solani (Martius) (Saccardo, 1881), has been isolated in crustaceans from gill lesions of cultured kuruma prawn Penaeus japonicus 
(Bate) (Bian et al., 1981) and from eggs of the triatomine bug Panstrongylus genicalatus (Latreille, 1811) causing reduction on egg hatching (Hartung and Lugo 1996). In addition, $F$. solani has also been described in a symbiotic relationship with the coleoptera Hypothenemus hampei (Ferrari, 1867), producing a significant increase in the progeny of females colonising coffee beans infested with F. solani (Morales-Ramos et al., 2000). However, despite the increasing knowledge of Fusarium spp. interaction with plants and animals, there is little information regarding this fungus relationship with scorpions. This work describes for the first time the invasive infection of the $F$. solani in T. stigmurus.

\section{Material and Methods}

In December 2005, 23 specimens of T. stigmurus collected in the field were donated to the Laboratory of Terrestrial Invertebrates (Laboratório de Invertebrados Terrestres), UFPE. Ten of these specimens were infected by fungus and died during the quarantine period. The external sign of fungus infection was observed as white mycelia covering the surface of the scorpion. The dead specimens were used to identify the species of fungus causing the animals' death. No individuals from the laboratory colony showed similar symptoms. During the quarantine period, animals were maintained under environmental conditions (temperature ranging from 25 to $29{ }^{\circ} \mathrm{C}$, relative humidity between $70-80 \%$ and average of 12 hours light/dark cycle). Specimens were kept in a terrarium $(30 \times 20 \times 20 \mathrm{~cm})$ made of glass, for easy visual monitoring, with a substrate of sand and gravels. Water and food (Periplaneta americana Linnaeus, 1758) were provided weekly. Using a standard aseptic technique, dead scorpions were rinsed with shaking in alcohol (70\%) and sodium hypoclorite (4\%). The surface sterilisation solution was removed by rinsing the animals for 2 minutes, with fresh sterile distilled water (Alves et al. 1998). The scorpions were transferred to a Petri dish containing BDA medium (Potato-Dextrose-Ágar) with antibiotic (Cloranfenicol). Plates were incubated at $28 \pm 1^{\circ} \mathrm{C}$ for 5 days. Pure fungal cultures were obtained by removing hyphal tips from actively growing mycelia emerging from the exoskeletons.

\section{Results and Discussion}

The fungal isolated from chelicerae and from the ventral part of the mesossoma (Figure 1) were analysed under lamina and identification was based on their morphological characteristics and colony colour.

Conidiophores branched bearing monophialides were observed. Micro-conidia abundant, ovoid or oblong, 0-1 septate, $8-16 \times 2-4 \mu \mathrm{m}$, formed from elongated conidiophores were also registered, as well as macro-conidia formed from short multi-branched conidiophores which may form sporodochia, 3-5 septate, fusiform, often moderately curved, $27-52 \times 4.4-6.8 \mu \mathrm{m}$ as described by (Nelson et al. 1983; Samson et al. 1996).

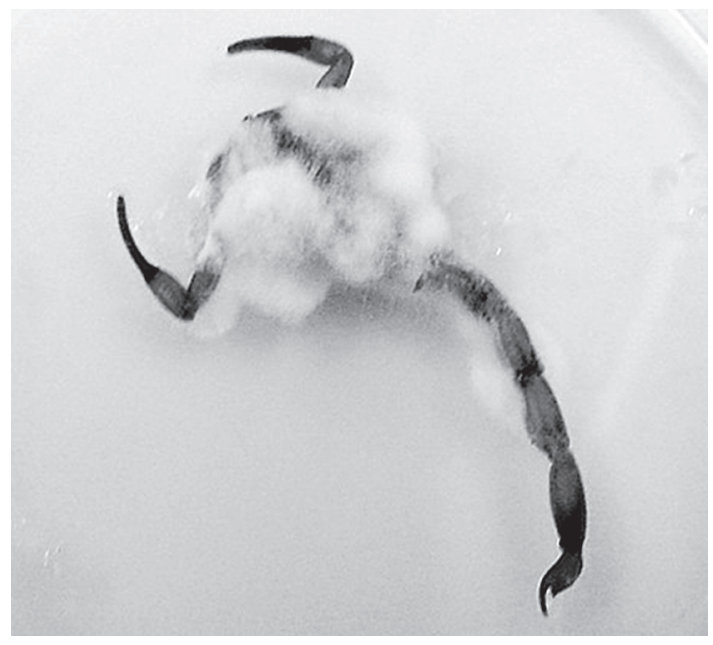

Figure 1. Tityus stigmurus naturally infected with Fusarium solani showing colony covering chelicera, carapace, and abdominal segments.

Infected scorpions showed behavioural changes by reducing walking and feeding activities. While uninfected individuals were continually active, infected specimens were motionless, not responding to the stimulus of touch near death. Behavioural changes due to fungus infection in scorpions has not been previouly described, however, in response to parasitism by entomopathogenic nematodes, the bark scorpion Centruroides exilicauda (Wood, 1863) showed modified walking and grooming patterns (Gouge and Snyder, 2005). According to these authors, infected specimens would hold their body high off the substrate when walking around; clean chelicerae and walk; and scrape their legs against their body. Behavioural changes due to $F$. solani infection have also been described in sharks with alterations in swimming patterns. Slowed down swimming, with occasional rapid bursts, was registered in infected sharks as the disease progressed (Crow et al., 1995).

In the advanced stages, black spots on the ventral part of the mesossoma were observed in some of the infected scorpions suggesting the occurrence of melanazation. Similar symptoms were described for gill lesions of the kuruma prawn $P$. japonicus associated with F. moniliforme (Sheldon, 1904) infection, presenting in the early stages a slight change in colours from opaque white to brown, leading to black spots on the gills (Rhoobunjongde et al. 1991).

Fungus infection in scorpions has been previously registered in Androctonus australis Hector (Gysin and Le Corroiler, 1969) and T. bahiensis (Matthiesen, 1984). However, no further comments on behaviour changes were performed in these studies. In A. australis infected with Aspergillus, superficial lesions showing chitine darkness and surface deformation reducing its defense capacity were described (Gysin and Le Corroiler, 1969).

One of the fungi features is to produce conidia over the body surface and this characteristic may lead to the 
successful spread of the fungus through the scorpion population. This indicates that $F$. solani may play a role as a mortality factor in T. stigmurus; however, the fact that this fungus has been reported as causing infections in humans makes it unsafe for biocontrol applications.

Acknowledgements - We are grateful to Dra. Zailde Ferraz and Mr. Roberto Braga from Health District II for their help with the collection of the scorpions, and Dra. Débora Maria Massa Lima for the identification of the fungal.

\section{References}

ALVES, SB., ALMEIDA, JEM., MOINO, JRA. and ALVES, LFA., 1998. Técnicas de laboratório. In ALVES, SB. (Ed.). Controle Microbiano de Insetos. Piracicaba: FEALQ. p. 637-711.

BIAN, BZ. and EGUSA, S., 1981. Histopathology of black gill disease caused by Fusarium solani (Martius) infection in the Kuruma prawn, Penaeus japonicus Bate. Journal of Fish Diseases, vol. 4, no. 3, p. 195-201.

BRASIL, 2001. Manual de diagnóstico e tratamento de acidentes por animais peçonhentos. 2 ed. Brasília: Fundação Nacional de Saúde. p. 37-44. (Escorpionismo).

CROW, GL., BROCK, JA. and KAISER, S., 1995. Fusarium solani fungal infection of the lateral line canal system in captive scalloped hammerhead sharks (Sphyrna lewini) in Hawaii. Journal of Wildlife Diseases, vol. 31, no. 4, p. 562-565.

GODOY,P., NUNES, F., SILVA, V., TOMIMORI-YAMASHITA, J., ZAROR, L. and FISCHMAN, O., 2004. Onychomycosis caused by Fusarium solani and Fusarium oxysporum in São Paulo, Brazil. Mycopathologia, vol. 157, no. 3, p. 287-290.

GOUGE, DH. and SNYDER, JL., 2005. Parasitism of Bark Scorpion Centruroides exilicauda (Scorpiones: Buthidae) by Entomopathogenic Nematodes (Rhabditida: Steinernematidae; Heterorhabditidae). Journal of Economic Entomology, vol. 98, no. 5 , p. 1486-1493.

GYSIN, J. and LE CORROILER, Y. 1969. Mycoses chez le scorpion 'Androctonus australis Hector'. Archives Institute Pasteur d'Aalgérié, vol. 47, p. 83-92.

HARTUNG, C. and LUGO, MR., 1996. Fusarium solani invader of the eggs of the insect Panstrongylus geniculatus in a vivarium. Mycopathologia, vol. 135, no. 3, p. 183-185.

LIRA da SILVA, RM., AMORIM, AM. and BRAZIL, TK., 2000. Envenenamento por Tityus stigmurus na região metropolitana de Salvador, Bahia, Brasil. Revista da Sociedade Brasileira Medicina Tropica, vol. 3, no. 3, p. 239-245.

LOURENÇO, WR. and EICKSTEDT, VRD., 2003. Escorpiões de importância médica. In CARDOSO, JLC., FRANÇA, FOS., WEN, FH., MÁlAQUE, CMS. and VIDAL Jr., H. (Eds.). Animais peçonhentos no Brasil: biologia, clínica e terapêutica dos acidentes. São Paulo: FAPESP. p. 182-197.

MATTHIESEN, FA., 1984. Revisão sobre parasitas e predadores de escorpiões. Naturalia, vol. 9, p. 1-5.

MORALES-RAMOS, JA., ROJAS, MG., SITTERTZBHATKAR, H. and SALDANA, G., 2000. Symbiotic relationship between Hypothenemus hampei (Coleoptera: Scolytidae) and Fusarium solani (Moniliales: Tuberculariaceae). Annals of the Entomological Society of America, vol. 93, no. 3, p. 541-547.

NELSON, PE., TOSSOUN, TA. and MARASAS, WFO., 1983. Fusarium species: an illustrated manual for identification. London: The Pensylvania State University Press. p. 193.

RHOOBUNJONGDE, W., HATAI, K., WADAS, S. and KUBOTA, S., 1991. Fusarium-moniliforme (sheldon) isolated from gills of kuruma prawn Penaeus-japonicus (bate) with black gill disease. Nippon Suisan Gakkaishi, vol. 57, no. 4, p. 629-635.

ROMANO, C., MIRACCO, C. and DIFONZO, EM., 1998. Skin and nail infections due to Fusarium oxysporum in Tuscany, Italy. Mycoses, vol. 41, no. 9, p. 433-437.

SAMSON, RA., HOEKSTRA, ES., FRISVAD, JC. and FILTENBORG, O., 1996. Introduction to Food-Borne Fungi. In SAMSON, RA., HOEKSTRA, ES., FRISVAD, JC. and FILTENBORG, O. (Eds.). Identification of the common food-borne fungi. Wageningen: Centraalbureau Voor Schimmelcultures. p. 322

SOARES, MRM., AZEVEDO, CS. and MARIA, M., 2002. Escorpionismo em Belo Horizonte, MG: um estudo retrospectivo. Revista da Sociedade Brasileira de Medicina Tropical, vol. 35, no. 4, p. 359-363.

ZHANG, N., O'DONNELL, K., SUTTON, DA., NALIM, FA., SUMMERBELL, RC., PADHYE, AA. and GEISERI, DM., 2006. Members of the Fusarium solani species complex that cause infections in both humans and plants are common in the environment. Journal of Clinical Microbiology, vol. 44, no. 6, p. 2186-2190. 